\title{
Article/Artigo
}

\section{Different culture media containing methyldopa for melanin production by Cryptococcus species}

\author{
Avaliação de diferentes meios de cultura contendo metildopa para a produção de melanina \\ por espécies de Cryptococcus
}

\author{
Ralciane de Paula Menezes ${ }^{1}$, Mário Paulo Amante Penatti ${ }^{2}$ and Reginaldo dos Santos Pedroso ${ }^{2}$
}

\begin{abstract}
Introduction: Melanin production by species of Cryptococcus is widely used to characterize C. neoformans complex in mycology laboratories. This study aims to test the efficacy of methyldopa from pharmaceutical tablet as a substrate for melanin production, to compare the production of melanin using different agar base added with methyldopa, and to compare the melanin produced in those media with that produced in Niger seed agar and sunflower seed agar by C. neoformans, C. laurentii, and C. albidus. Two isolates of each species, C. neoformans, C. laurentii, and C. albidus, and one of Candida albicans were used to experimentally detect conditions for melanin production. Methods: The following media were tested: MuellerHinton agar (MHA), brain and heart infusion agar (BHIA), blood agar base (BAB), and minimal medium agar (MMA), all added with methyldopa, and the media Niger seed agar (NSA) and sunflower seed agar (SSA). Results: All isolates grew in most of the culture media after $24 \mathrm{~h}$. Strains planted on media BAB and BHIA showed growth only after $48 \mathrm{~h}$. All isolates produced melanin in MMA, MHA, SSA, and NSA media. Conclusions: Methyldopa in the form pharmaceutical tablet can be used as a substrate for melanin production by Cryptococcus species; minimal medium plus methyldopa was more efficient than the BAB, MHA, and BHIA in the melanin production; and NSA and SSA, followed by MMA added with methyldopa, were more efficient than other media studied for melanin production by all strains studied.
\end{abstract}

Keywords: Cryptococcus sp. Melanin. Culture media. Methyldopa.

\section{RESUMO}

Introdução: A produção de melanina por espécies de Cryptococcus é uma característica amplamente utilizada em laboratórios de micologia para caracterização do complexo C. neoformans. O objetivo deste estudo foi verificar a eficácia da metildopa na forma farmacêutica de comprimido, como substrato para a produção de melanina por Cryptococcus, comparar diferentes bases de meios de cultura acrescidas de metildopa para produção de melanina e comparar o pigmento produzido nestes meios com o produzido em ágar Níger e ágar girassol por C. neoformans, C. laurentii e C. albidus. Métodos: Foram testados dois isolados de cada uma das espécies, C. neoformans, C.laurentii e C.albidus, e um de C. albicans para avaliar a produção de melanina nos meios de cultura ágar Müeller-Hinton (MH), ágar brain heart infusion (BHI), ágar base sangue (BS), meio mínimo (MM), todos acrescidos de metildopa, e ainda ágar girassol e ágar Níger. Resultados: Todos os isolados cresceram na maioria dos meios após $24 \mathrm{~h}$. O crescimento nos meios BS e BHI somente ocorreu após $48 \mathrm{~h}$. Todos os isolados produziram melanina nos meios MM, MH, girassol e Niger. Conclusões: A metildopa de origem farmacêutica pode ser utilizada como substrato para a produção de melanina por espécies de Cryptococcus; o MM acrescido de metildopa mostrou-se mais eficiente na produção de melanina do que os meios BS, MH e BHI; ágar girassol e ágar Níger seguidos de MM acrescido de metildopa foram os mais eficientes na produção de melanina pelos isolados estudados.

Palavras-chaves: Cryptococcus sp. Melanina. Meios de cultura. Metildopa.

1. Instituto de Ciências Biomédicas, Universidade Federal de Uberlândia, Uberlândia, MG. 2. Curso Técnico em Análises Clínicas, Escola Técnica de Saúde, Universidade Federal de Uberlândia, Uberlândia, MG. Address to: Dr. Reginaldo dos Santos Pedroso. Curso Técnico em Análises Clínicas/ESTES/UFU. Av. Amazonas s/n, Bloco 4K, sala 110, Umuarama, 38400-902 Uberlândia, MG, Brasil.

Phone: 5534 3218-2218; Fax: 5534 3218-2410

e-mail: rpedroso@estes.ufu.br

Received in 07/03/2011

Accepted in 19/05/2011

\section{INTRODUCTION}

Cryptococcus neoformans and C. gattii are the main species of the Cryptococcus genera involved in clinical cases of cryptococcosis. Other species are less common, but two of these, C. albidus and C. laurentii, represent about $80 \%$ of clinical isolates excluding neoformans and gattii species ${ }^{1}$.

Infections caused by $C$. neoformans occur more frequently in immunocompromized individuals, while C. gattii is often found infecting immunocompetent ones ${ }^{2}$. Other species of the genus have been isolated mostly in individuals with some type of immunodeficiency ${ }^{1}$.

The laboratory identification of medical important Cryptococcus species takes into account the particular characteristics of this genus. The majority are yeasts that produce capsules, are able to grow at $37^{\circ} \mathrm{C}$, and produce enzymes urease and laccase. When cultured in media containing phenolic or polyphenolic substrates, they form a pigment called melanin ${ }^{3}$. Enzyme laccase present in yeast acts on these phenolic substrates generating quinones, which undergo a process of autopolimerization and turn into melanin. The dark pigment retained in the cell wall of the fungus is responsible for the color shown by the colonies ${ }^{4,5}$. Other species of Cryptococcus may also produce melanin in the media, but not so intensely as C. neoformans and C. gattii ${ }^{6,7}$.

Colonies of melanin-producing Cryptococcus species show a display of colors varying from brown to black when grown in agar media such as sunflower seed agar (Helianthus annus), Niger seed agar (Phalaris canariensis), birdseed agar (Guizotia abyssinica), potatocarrot agar, and other chemically defined media as L-dopa and caffeic acid agar 7 . Some recent studies have shown the production of pigment in mustard seed and chilli pepper agar, Pinus halepensis seed and blackberry agar, and in media containing substrates methyldopa, epinephrine, and norepinephrine $e^{8-12}$.

While the proposed natural resources are easily found and inexpensive, they undergo a complex preparation. So we proposed this study with the 
following objectives: I) to test the efficacy of methyldopa from a pharmaceutical tablet as a substrate for melanin production; II) to compare the production of melanin using different agar base added with methyldopa; and III) to compare the melanin produced in those media with that produced in Niger seed agar and sunflower seed agar by C. neoformans, C. laurentii, and C. albidus.

\section{METHODS}

\section{Culture media}

The following media were experimentally tested: Mueller-Hinton agar (MHA) (Isofar; Duque de Caxias, State of Rio de Janeiro, Brazil), brain and heart infusion agar (BHIA) (Biobrás, Belo Horizonte, State of Minas Gerais, Brazil), blood agar base (BAB) (Biobrás, Belo Horizonte, MG, Brazil), Niger seed agar (NSA), and sunflower seed agar (SSA). The minimal medium (MMA) composition per liter was: $20 \mathrm{~g}$ of bacteriological agar (BIOBRÁS; Belo Horizonte, MG, Brazil), $5 \mathrm{~g}$ of ammonium sulfate (Vetec; Duque de Caxias, RJ, Brazil), $2 \mathrm{~g}$ of glucose (Isofar; Duque de Caxias, RJ, Brazil), $1 \mathrm{~g}$ of yeast extract (Vetec; Duque de Caxias, RJ, Brazil), and $0.2 \mathrm{~g} / \mathrm{L}$ of methyldopa. Methyldopa (MD) (Medley; Campinas, State of São Paulo, Brazil) was acquired in the form of pharmaceutical tablets, weighed, and pulverized with the aid of mortar and pestle. The MMA was prepared by weighing the reagents described plus methyldopa, the $\mathrm{pH}$ adjusted between 5 and 6 , and then sterilized and distributed in plates. MHA (composition: meat infusion $-5 \mathrm{~g} / \mathrm{L}$; hydrolyzed casein $17.5 \mathrm{~g} / \mathrm{L}$; cornflour $-1.5 \mathrm{~g} / \mathrm{L}$; agar-agar $-15 \mathrm{~g} / \mathrm{L})$, BHIA (composition: gelatin peptone $-10.5 \mathrm{~g} / \mathrm{L}$; infuse of brain and heart $-6 \mathrm{~g} / \mathrm{L}$; meat peptone $-11 \mathrm{~g} / \mathrm{L}$; dextrose $-20 \mathrm{~g} / \mathrm{L}$; sodium chloride $-5.0 \mathrm{~g} / \mathrm{L}$; sodium phosphate biphasic $-2.5 \mathrm{~g} / \mathrm{L})$, and $\mathrm{BAB}$ (composition: casein peptone $-17.5 \mathrm{~g} / \mathrm{L}$; yeast extract $4.12 \mathrm{~g} / \mathrm{L}$; cornflour $-1.5 \mathrm{~g} / \mathrm{L}$; bacteriological agar $-15 \mathrm{~g} / \mathrm{L}$; sodium chloride $-5.0 \mathrm{~g} / \mathrm{L}$ ) were prepared according to manufacturer's instructions. After the addition of methyldopa, the $\mathrm{pH}$ was adjusted between 5 and 6 , and the complete medium was sterilized by
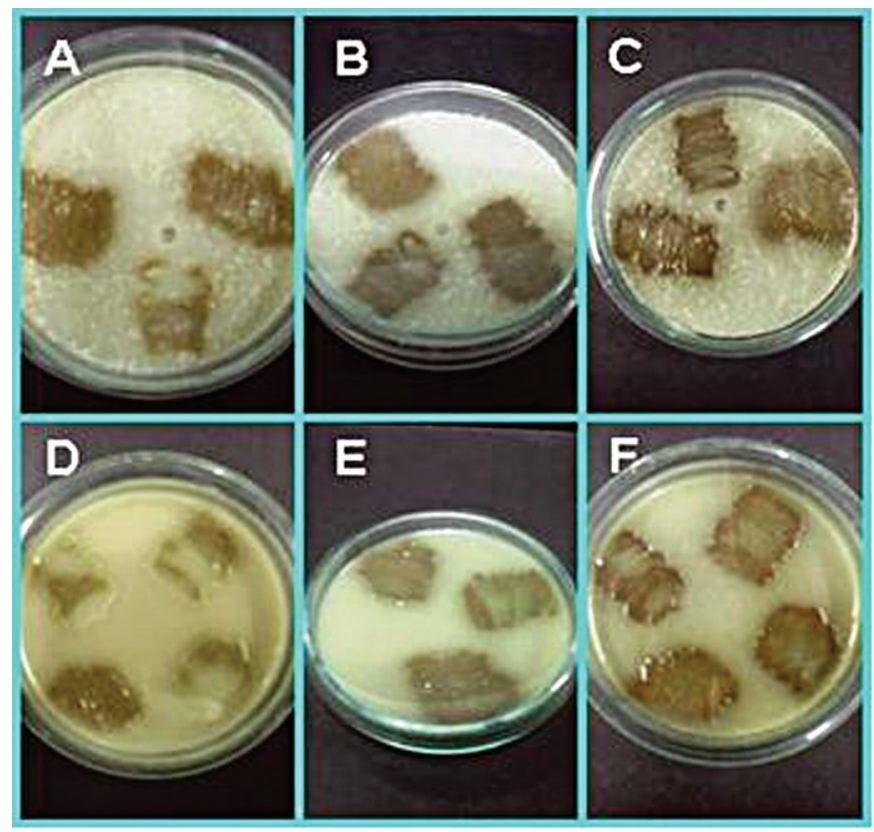

FIGURE 1 - Melanin produced by Cryptococcus neoformans in a traditional media for producing pigment.

A (24h), B (48h), and C (8 days): Sunflower seed agar. D (24h), E (48h), and F ( 8 days): Niger seed agar. autoclaving at $121^{\circ} \mathrm{C}$ for $15 \mathrm{~min}$ and distributed in polystyrene, 90x15mm Petri dishes. The NSA and SSA were prepared by boiling 70 g of the respective seeds in $500 \mathrm{~mL}$ of distilled water for $30 \mathrm{~min}$ followed by processing in a blender and filtration through gauze. Twenty grams of bacteriological agar (BIOBRÁS, Belo Horizonte, MG, Brazil) were added to the filtrate, the volume adjusted to $1,000 \mathrm{~mL}$, sterilized by autoclaving at $121^{\circ} \mathrm{C}$ for $15 \mathrm{~min}$, and distributed in Petri dishes.

\section{Microorganisms}

The microorganisms used in the tests were two strains of C. neoformans (ATCC 90112, var. grubii and ATCC 28957, var. neoformans), two strains of C. laurentii (CRL05 and CRL12), two strains of C.albidus (CRA01 and CRA04), and one strain of Candida albicans (ATCC 64548), as a negative control for melanin production (previously tested and non-melanin producer). The microorganisms were kept at $4{ }^{\circ} \mathrm{C}$ in tubes containing Sabouraud dextrose agar (SDA), and subcultured every month.

According to the experimental design, portions of each microorganism colony (previously incubated at $30^{\circ} \mathrm{C}$ for $72 \mathrm{~h}$ on SDA) were collected with a sterile disposable loop $1 \mu \mathrm{L}$, and planted on the surface of the media under study. Four or five colony samples were planted on each plate. The tests were performed in duplicate and in two independent experiments. The plates were incubated at $30^{\circ} \mathrm{C}$ and observed at $24,48,72$, and $96 \mathrm{~h}$ and on the $8^{\text {th }}$ day to check the variation of colony pigmentation.

The expression of results was performed by grouping the isolates with the same intensity of pigmentation and classifying them by the score: 0 (zero) for colonies with absence of pigments, 1 for a light brown, 2 for brown, and 3 for black colonies.

\section{RESULTS}

All isolates grew on most of the culture media studied after 24h of incubation. Isolates of C. neoformans, C laurentii, and C. albidus showed growth in BAB and BHIA only after $48 \mathrm{~h}$ of incubation. Table 1 shows the scores for melanin production by different isolates in the different media, according to incubation time.

The color of the colonies was stable from 4 to 8 days of incubation, for all isolates and on all media studied. Colonies of C. albicans showed no melanoid pigmentation, remaining colorless during all periods of incubation in all media. Figures $\mathbf{1}$ and $\mathbf{2}$ show the melanin production in different media by the Cryptococcus strains and C. albicans.

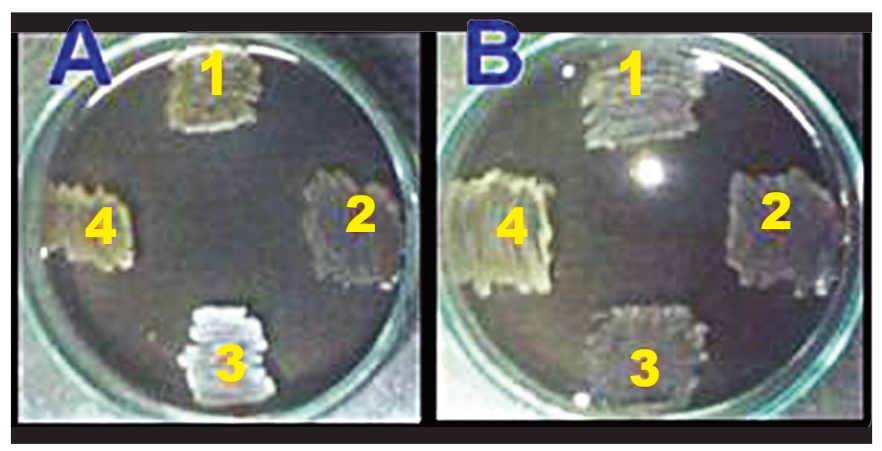

FIGURE 2 - Melanin produced by Cryptococcus spp. in a minimal medium containing methyldopa after $72 \mathrm{~h}$ of incubation.

A) 1 and 4: Cryptococcus neoformans; 2: Cryptococcus albidus; 3: Candida albicans; B) 1 and 2: Cryptococcus albidus; 3: Cryptococcus laurentii; 4: Cryptococcus neoformans. 


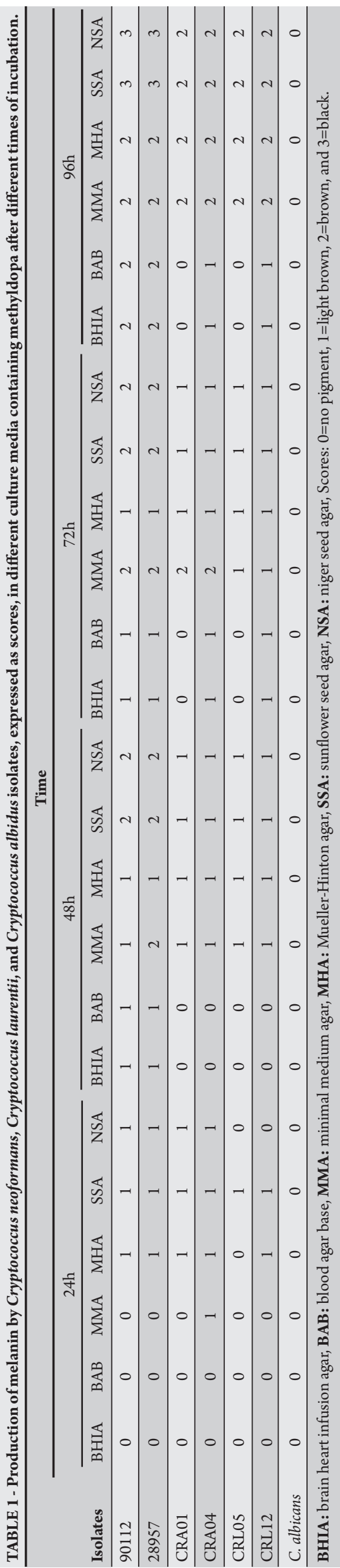

\section{DISCUSSION}

The concept of formulating differential and efficient culture media for the isolation and identification of pathogenic fungi, such as the genus Cryptococcus, is not new. Specific, differential, and selective media are often sought for certain groups, genera, or species of microorganisms. Thus, an ideal medium would facilitate the work of the mycologist, reducing the processing time of culture and identification of the fungus, besides the low cost and easy-to-prepare, -to-standardize, and -to-interpret results. However, many problems, such as a dubious and time-consuming interpretation of results, have hampered the achievement of this goal. In this way, many studies have been performed to formulate a culture medium that is effective for the presumptive identification and differentiation of isolates of the C. neoformans complex.

This study analyzed a culture medium composed by a few components, which were of low cost, easy to prepare, and able to show production of melanin by the species C. neoformans, C. albidus, and C. laurentii. The medium was prepared using methyldopa of pharmaceutical origin as a substrate for the melanin production; methyldopa was used because of its low cost and being available at the pharmacies in Brazil.

In laboratory practice, chemically defined media have been employed, with the advantage of known constituents, but media prepared with natural resources, such as Niger seed agar, are widely used by some authors ${ }^{13}$. In the present study, low concentrations of glucose and yeast extract were added to the culture media to provide the elements necessary to accelerate growth and melanin expression. However, this procedure was positive only for growth, as melanin production was not affected. The early oxidation of agar was inhibited and extended from as early as $24 \mathrm{~h}$ to after $72 \mathrm{~h}$ of incubation by the adjustment of $\mathrm{pH}$ between 5 and 6 that allowed better interpretation of the results.

Niger seed agar, sunflower seed agar and minimal medium agar showed growth and pigmentation of the isolates under study in a shorter period of time (24-72h). BHIA, $\mathrm{BAB}$, and MHA media plus methyldopa showed slight change in color of the colonies of C. neoformans after $48 \mathrm{~h}$ of incubation. The C. albicans strain did not produce darkpigmented melanin during the study. This is important to be mentioned because C. albicans is able to produce melanin under certain laboratory conditions ${ }^{14}$. Similar results to those presented with SSA, NSA, and MMA were observed by Mseddi et al. ${ }^{12}$ in both the Pinus halepensis agar and the blackberry agar, and by Pedroso et al. ${ }^{7}$ in the L-dopa agar. Hernández et al. ${ }^{9}$ also evaluated the production of melanin in sunflower seed agar by C. neoformans isolates and found that most isolates produced an intense pigmentation.

The culture media used in this study appear to give faster results in the expression of melanin than the Mucuna pruriens agar ${ }^{15}$. In this medium, the authors showed that colonies of $C$. neoformans changed colors only between the third and fifth days of incubation. In another recent study ${ }^{12}$ using seeds of Pinus halepensis and blackberry in the production of a new culture media for isolation of Cryptococcus species, the results obtained were satisfactory, and the medium was simple to prepare and enabled a rapid and presumptive identification of C. neoformans.

Comparison of melanin production among isolates of Cryptococcus species revealed that $C$. neoformans isolates formed colonies with stronger color in a shorter time than the isolates of C. laurentii and C. albidus, in all media. According to Ikeda et al., ${ }^{6}$ this occurs because the enzyme activity of phenoloxidase in all strains of the genus Cryptococcus other than the C.neoformans complex is lower, including in several clinically emerging species that express melanin. Regarding the identification of C. neoformans, the melanin pigment in Niger seed agar, sunflower seed agar, and minimal medium agar supplemented with methyldopa, was a good indicator of presumptive identification in 24-72h of incubation.

We concluded that: I) methyldopa in the form pharmaceutical tablet can be used as a substrate for melanin production by Cryptococcus species; II) minimal medium plus methyldopa was more efficient than the $\mathrm{BAB}, \mathrm{MHA}$, and $\mathrm{BHIA}$ in the melanin production by strains studied; and III) NSA and SSA, followed by MMA, added with methyldopa were more efficient than the other media studied in providing evidence of melanin production by C. neoformans, C. laurentii, and C. albidus strains studied. 


\section{ACKNOWLEDGMENTS}

The authors are grateful to the technical assistance of Larice Faria da Cunha, Lara de Andrade Marques, Gabriel de Oliveira Faria, and Adriano Gonçalves Martins, for their help in carrying out some experiments.

\section{CONFLICT OF INTEREST}

The authors declare that there is no conflict of interest.

FINANCIAL SUPPORT

R. P. Menezes has a PIBIC/CNPq/UFU scholarship.

\section{REFERENCES}

1. Khawcharoenporn T, Apisarnthanarak A, Mundy LM. Non-neoformans cryptococcal infections: a systematic review. Infection 2007; 35:51-58.

2. Kurtzman CP, Fell JW. The Yeasts: a taxonomic study. $4^{\text {th }}$ ed. New York; 1998.

3. Lacaz CS, Porto E, Martins JEC. Micologia médica: fungos, actinomicetos e algas de interesse médico. $8^{\text {th }}$ ed. São Paulo: Sarvier; 1991.

4. Casadevall A, Rosas AL, Nosanchuk JD. Melanin and virulence in Cryptococcus neoformans. Curr Opin Microbiol 2000; 3:354-358.

5. Polacheck I, Hearing VJ, Kwon-Chung KJ. Biochemical studies of phenoloxidase and utilization of catecholamines in Cryptococcus neoformans. J Bacteriol 1982; 150:1212-1220.

6. Ikeda R, Sugita T, Jacobson ES, Shinoda T. Laccase and melanization in clinically important Cryptococcus species other than Cryptococcus neoformans. J Clin Microbiol 2002; 40:1214-1218.

7. Pedroso RS, Costa KRC, Ferreira JC, Candido RC. Evaluation of melanin production by Cryptococcus species in four different culture media. Rev Soc Bras Med Trop 2007; 40:566-568.

8. Garcia-Rivera J, Eisenman HC, Nosanchuk JD, Aisen P, Zaragoza O, Moadel T, et al. Comparative analysis of Cryptococcus neoformans acid-resistant particles generated from pigmented cells grown in different laccase substrates. Fungal Genet Biol 2005; 42:989-998.

9. Hernández ICV, Machín GM, Andreu CMF, Zaragozi MTI. Pigmentación de cepas de Cryptococcus neoformans sobre agar semilla de girassol. Rev Cubana Med Trop 2003; 55:119-120.

10. Nandhakumar B, Kumar CPG, Pradu D, Menon T. Mustard Seed Agar, a new medium for differentiation of Cryptococcus neoformans. J Clin Microbiol 2006; $44: 674$.

11. Stepanovic S, Vikovic D, Radonjic I, Dimitrijevic V, Svabic-Vlahovic M. Ground red hot pepper agar in the isolation and presumptive identification of Cryptococcus neoformans. Mycoses 2002; 45:684-688.

12. Mseddi F, Sellami A, Sellami H, Cheikhrouhou F, Makni F, Ayadi A. Two new media Pinus halepensis seed agar and blackberry agar for rapid identification of Cryptococcus neoformans. Mycoses 2011; 54:350-353.

13. Paliwal DK, Randhawa HS. Evaluation of a simplified Guizotia abyssinica seed medium for differentiation of Cryptococcus neoformans. J Clin Microbiol 1978; 7:346-348.

14. Morris-Jones R, Gomez BL, Diez S, Uran M, Morris-Jones SD, Casadevall A, et al. Synthesis of melanin pigment by Candida albicans in vitro and during infection. Infect Immun 2005; 73:6147-6150.

15. Gokulshankar S, Babu K, Valli S, Ranjitsingh AJ, Ranjith MS. Cowitch seed agar medium - a simple new medium for identification and melanin production of Cryptococcus neoformans. Mycoses 2011; 54:e208-e210. 